Research article

\title{
Management of slurry in Gran Canaria Island with full-scale natural treatment systems for wastewater (NTSW). One year experience in livestock farms
}

\author{
Carlos A. Mendieta-Pino ${ }^{\mathrm{a}}$, Alejandro Ramos-Martin ${ }^{\mathrm{b}, *}$, Sebastian O. Perez-Baez ${ }^{\mathrm{a}}$, \\ Saulo Brito-Espino ${ }^{\mathrm{a}}$
}

${ }^{a}$ Institute for Environmental Studies and Natural Resources (i-UNAT), University of Las Palmas de Gran Canaria, Spain

${ }^{\mathrm{b}}$ Process Engineering Department, University of Las Palmas de Gran Canaria, Spain

\section{A R T I C L E I N F O}

\section{Keywords:}

Natural systems

Anaerobic digester

Slurry management

Wastewater treatment

Constructed wetlands

Ponds

COD removal efficiency

Low-cost treatment

\begin{abstract}
A B S T R A C T
The aim of this work is to describe the performance of three full-scale natural treatment systems for wastewater, which operated in an integrated manner in livestock pig farms (1000 - 1500 pigs in total) over one year. Slurry management was performed with these natural treatment systems operating under the normal waste loading conditions of the livestock farms in which were integrated. The systems were comprised of elements such as first generation digesters, subsurface flow constructed wetlands and facultative ponds. The facilities, located on the island of Gran Canaria (Spain), enabled the study of viable alternatives for effluent management characterized by low-cost treatments. The systems were evaluated in terms of chemical oxygen demand removal efficiency, operating with variable organic loading. Values of between $80 \%$ and $90 \%$ were obtained. A comparison was also made of first-generation cascade flow digester operation $(<70 \%$ removal efficiency), with complete-mix digesters $(<20 \%$ removal efficiency), and finally with facultative ponds combined with subsurface flow constructed wetlands $(<91 \%$ removal efficiency). It was also verified that when natural treatment systems for wastewater combine different elements they have better removal efficiency and better response to load and/or flow changes.
\end{abstract}

\section{Introduction}

Since the first use of livestock farms, an equilibrium has been required between the number of animals and the amount of land needed for their exploitation (Campos and Flotats-Ripoll, 2001). However, the progressive development of intensive livestock farming and the increase in animal density have resulted in farm waste becoming a serious management problem. Various attempts have been made to resolve the problem including, for example, the search for suitable processes to reuse the waste as fertilizer (Basset-Mens and van der Werf, 2005). Farm waste has caused contamination of land and groundwater in many parts of the planet, a situation which has created environmental problems in certain geographical areas of the world. Various authors have identified these areas and have elaborated nutrient concentration maps for a wide variety of crops (Murgueitio, 2003; Alfaro and Salazar, 2005; Escribano-Pintor et al., 2010; Gallego, 2014; Gross and Hagy, 2017; Hopkins et al., 2017; Rivas et al., 2017; Perez-Rodriguez et al., 2017; Mabilde et al., 2017; Alvarez-Romero et al., 2014). In addition, in small territories, such as islands which are usually characterized by a set of small communities, farm waste management is even more complex as these populations tend to be scattered throughout the territory. It has been shown that natural treatment systems for wastewater (NTSW) are suitable in these circumstances for small communities thanks to their low energy and operating costs (Vera et al., 2009, 2013). Various studies have reached the following conclusions in relation to NTSW (Mendieta et al., 2008; Caballero-Lajarin et al., 2008; Caballero-Lajarin, 2013; Lopez et al., 2008; Bennett and Warren, 2015):

1. NTSW applied to island farm livestock effluents, and more specifically pig farms, have shown good results in waste treatment.

2. Waste management is performed at the farm, with intensive re-use and a second stage involving the discharge of stabilized effluent into the public sewage system.

In addition, $\boldsymbol{N T S W}$ are characterized as treatment systems, in which the effluents are stored for long periods, depending on the

\footnotetext{
* Corresponding author.

E-mail addresses: carlos.mendieta@ulpgc.es (C.A. Mendieta-Pino), alejandro.ramos@ulpgc.es (A. Ramos-Martin), sebastianovidio.perez@ulpgc.es (S.O. Perez-Baez), saulobrito09@gmail.com (S. Brito-Espino).
} 
applied load and the climatic conditions, and in which the organic matter is degraded by bacterial activity (Crites et al., 2014). The $\boldsymbol{N T S W}$ are also known in scientific and technical literature as unconventional technologies, low cost systems, soft technologies and green systems, among others. The two fundamental differences between natural and conventional systems are the zero energy consumption, and larger treatment surface area of the former (Gachango et al., 2015; Mannino et al., 2008).

The $\boldsymbol{N T S W}$ take advantage of and synergyse physical, chemical and biological processes that are spontaneously manifested in nature. It has been proven that $\boldsymbol{N T S W}$ are equally suitable for urban and rural applications, with high pollutant removal capacity and appropriate effluent reuse (Gearheart, 1992; Yoon et al., 2008; Vera-Pena et al., 2005; Ayaz and Akca, 2000; Ayaz and Aka, 2001; Belmont et al., 2004; Bernal et al., 2008; Xu et al., 2010; Crites et al., 2014).

All NTSW must be preceded by mechanical pre-treatment processes, including sieving or primary sedimentation, which eliminates coarse solids, and prevents obstructions and/or unpleasant conditions (Hjorth et al., 2010). The $\boldsymbol{N T S W}$ are carried out using several types of subsystems, including ponds, constructed wetlands and anaerobic digesters (first generation models), each of which facilitates a series of natural processes (Crites et al., 2014).

The aim of this paper is to describe the study of pig livestock waste management with three types of experimental pilot plant at steady state operation, on the island of Gran Canaria (Spain). These experimental plants are based on NTSW and have been designed with different elements and configurations to assess and validate their operation in real pig livestock farms integrated in small communities, which are typical population nuclei on Gran Canaria. The three pilot plants were designed with pre-treatment rotary screen.

As is also the case with the other islands in the Canary Archipelago, Gran Canaria, with a surface area of $1560 \mathrm{~km}^{2}$, and extensive environmental protection areas, has become a territory with general farm waste management problems, and intensive pig waste problems. As indicated in the Canary Islands Integral Waste Plan (Gobernment, 2001), in many areas of the island there are several problems of contamination due to the uncontrolled dumping of livestock waste, which can cause nitrate contaminations of groundwater and aquifers, land degradation and bad odours.

There are presently 136 livestock pig farms in Gran Canaria, although the great majority, $90 \%$, are small family farms with few animals. Only 14 of the farms have $50-100$ breeding sows or more, and these farms account for almost $75 \%$ of the pig census of the island. These farms have a major waste impact, as they represent around $1000-1500$ animals in a closed cycle in one year of production. This is equivalent in term of organic load, to a population of between 2000 and 3000 inhabitants or the population of a complete village or small town of Gran Canaria. Fig. 1 shows, on the left, all the livestock farms (red dots) on Gran Canaria and, on the right, the specific location of the three livestock farms where the natural treatment systems were applied.

\section{Materials and methods}

In this section, a description is given of the specifically designed and manufactured pilot plants, as well as the different operating processes and sampling methods. The main selection and design criteria for livestock farms are shown, based on the pig farm characteristics, and the targets established for the pilot plants. The most important characteristics of the pilot plants are explained, as well as the sampling points to monitor the evolution of the purification processes. Finally, the studied parameters and sampling frequency are indicated.

\subsection{Livestock farm selection criteria and systems}

Based on the established targets, the following selection and design criteria were proposed for each of the following aspects: farm characteristics, proposed anaerobic digesters, ponds and constructed wetland.

- Farm selection criteria:

1. Well stablished farms with long-term operating experience and medium-term assurance of continued operation.

2. Closed cycle farm operation.

3. Farm population of $90-150$ sows, ensures a minimum threshold of economic profitability at industrial exploitation level.

4. Farms located in relatively remote rural environments, a common occurrence with farms on the island.

5. In normal farm operation, generation of waste effluent batches in a period ranging between 3 and 5 days.

- Selection and design criteria for first generation anaerobic digesters:

1. Minimum residence time of 10 days.

2. Digesters with regular geometries (quadrangular prisms) in order to ensure slurry flow.

3. Digesters without biogas recovery systems (these can be installed in future expansions).

4. Digesters half-buried to help maintain a balanced temperature throughout the year.

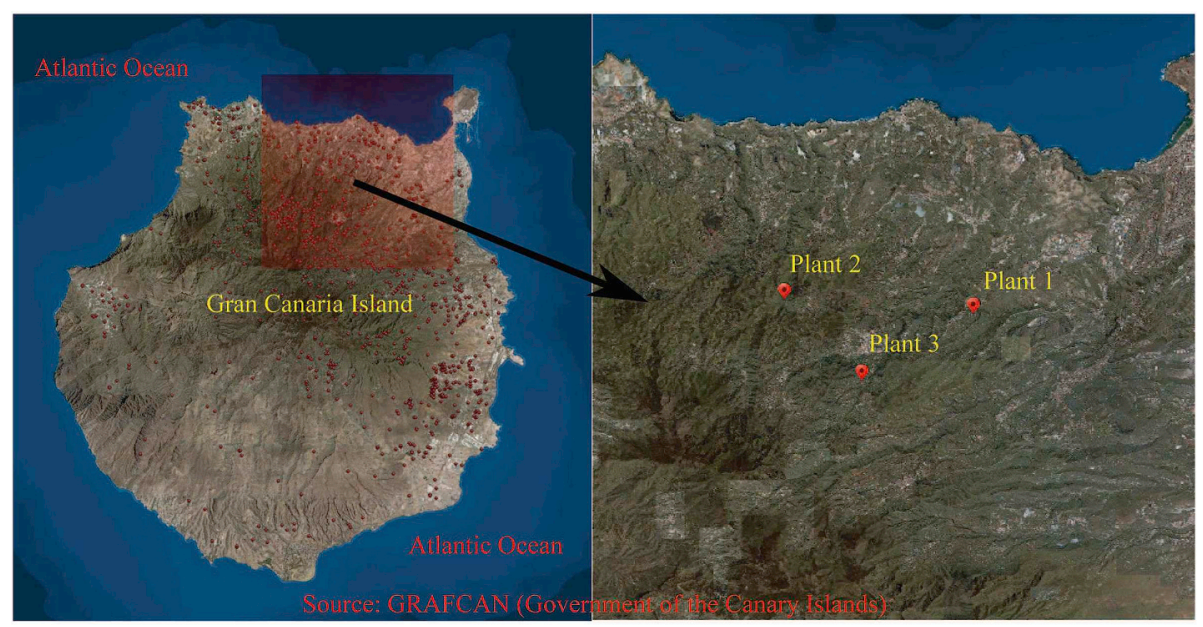

Fig. 1. Plant locations in Gran Canaria. Source GRAFCAN (Government of the Canary Islands). 
Table 1

Data pilot Plants.

\begin{tabular}{|c|c|c|c|c|c|c|c|}
\hline Plant & $\begin{array}{l}\text { Farm effluent } \\
\text { COD } \\
(\text { ppm })\end{array}$ & $\begin{array}{l}\text { Effective flow rate } \\
\text { Qeff } \\
\left(m^{3} / d a y\right)\end{array}$ & $\begin{array}{l}\text { Breeding sows - Total pigs } \\
\mathbf{N}_{\mathbf{B r}}-\mathbf{N}_{\mathbf{T}}\end{array}$ & \multicolumn{4}{|c|}{ Volume - Hydraulic retention time } \\
\hline 1 & 29,773 & 13.60 & $(180)-(1890)$ & $(15)-(1)$ & - & - & $(1100)-(80)$ \\
\hline 2 & 18,381 & 6.40 & $(115)-(1068)$ & $(40)-(6)$ & $(132)-(21)$ & - & \\
\hline 3 & 21,424 & 8.70 & $(160)-(1432)$ & $(10)-(1)$ & $(103)-(11)$ & $(46)-(5)$ & $(90)-(10)$ \\
\hline
\end{tabular}

5. Each digester with an initial chamber that serves as homogenization/reception chamber and first sedimentation of solids. A rotary screen is attached to this chamber.

- Selection and design criteria for ponds and subsurface flow constructed wetlands:

1. Anaerobic ponds with irregular geometry (right rectangular prisms) with a length/width ratio of $2: 1$ and depth of $1.50 \mathrm{~m}$.

2. Subsurface flow constructed wetlands (SSFCW) with irregular geometry (right rectangular prisms), a length/width ratio of 2: 1 and depth of $3.0 \mathrm{~m}$.

\subsection{Description of pilot plants and sampling points}

The pilot plants are located inland on Gran Canaria Fig. 1. The most important characteristics of the three plants are shown below. A summary of the main properties is shown in Table 1, and a schematic representation of the plants in Fig. 2, including the sampling points.

- Plant 1. Located in the municipality of Las Palmas de Gran Canaria at an altitude of $450 \mathrm{~m}\left(28^{\circ} 4.36^{\prime} \mathrm{N}, 15^{\circ} 30.51^{\prime} \mathrm{W}\right)$, along with a pig farm of 1890 heads. Farm effluent is discharged at a flow rate of

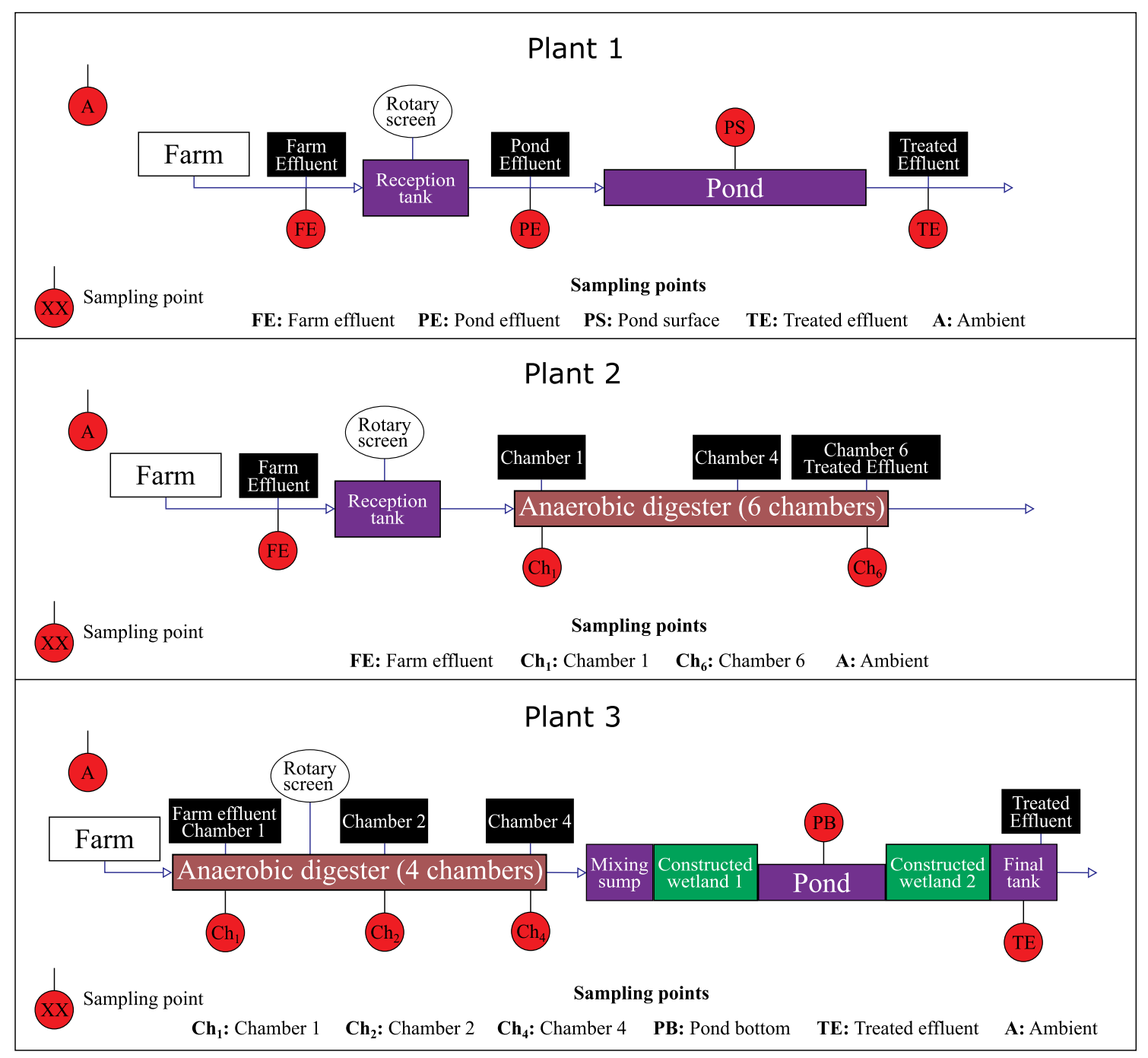

Fig. 2. Schematics of the plants and sampling points. 
$13.60 \mathrm{~m}^{3} /$ day into a $15 \mathrm{~m}^{3}$ reception tank. Once the reception tank is filled, the stored effluent is screened with a $100 \mu \mathrm{m}$ rotary sieve and solid fraction is deposited in a drying zone. In turn, the liquid fraction is pumped into a pond with a $2 / 1$ length/width ratio, an effective capacity of $1100 \mathrm{~m}^{3}$ and depth of $1.5 \mathrm{~m}$. Global hydraulic retention time $H R T$ is 81 days.

- Plant 2. Located in the municipality of Firgas at an altitude of $540 \mathrm{~m}$ $\left(28^{\circ} 4.68^{\prime} \mathrm{N}, 15^{\circ} 34.52^{\prime} \mathrm{W}\right)$, along with a pig farm of 1068 animals. Farm effluent is discharged at a flow rate of $6.40 \mathrm{~m}^{3} /$ day into a $40 \mathrm{~m}^{3}$ reception tank with a retention time of $4-6$ days. Once the reception tank is filled, the stored effluent is screened with a $100 \mu \mathrm{m}$ rotary sieve and the solid fraction is deposited in a drying zone. In turn, the liquid fraction is pumped to a digester, which is a halfburied right rectangular prism with dimensions of $17.50 \mathrm{~m} \times 6.50 \mathrm{~m} \times 3.50 \mathrm{~m}$ and an effective height of $1.70 \mathrm{~m}$. The digester is comprised of six chambers with a square base dimensions of $3.00 m \times 3.00 \mathrm{~m}$. The six chambers are alike and arranged in series by means of siphons, making it possible to assimilate them to a cascade digester. Each chamber has an effective capacity of $22 \mathrm{~m}^{3}$, and the digester has a total capacity of $132 \mathrm{~m}^{3}$. Global HRT is 27 days.

- Plant 3. Located in the municipality of Teror, at an altitude of $700 \mathrm{~m}$ $\left(28^{\circ} 2.83^{\prime} \mathrm{N}, 15^{\circ} 32.87^{\prime} \mathrm{W}\right)$, along with a pig farm of 1432 heads. Farm effluent is discharged into a $10 \mathrm{~m}^{3}$ capacity reception tank at a flow rate of $8.70 \mathrm{~m}^{3} /$ day. Once the reception tank is filled, the stored effluent is taken to the first chamber of a digester which is comprised of four rectangular prism shaped chambers, which are alike and arranged in series, with a total effective capacity of $103.00 \mathrm{~m}^{3}$ and a residence time of $10-12$ days. This geometry favours the mixing processes and can be associated, in each chamber, to a complete mix digester. Chambers 2, 3 and 4 are interconnected by means of siphons. When chamber 1 is filled, every 2 or 3 days, the stored effluent is screened with a $100 \mu \mathrm{m}$ rotary sieve and the solid fraction is deposited in a drying zone. In turn, the liquid fraction is pumped into chamber 2, which overflows into chamber 3 , and chamber 3 into chamber 4 . In the same way as liquid from the different chambers (from 2 to 4 ) overflows and passes from one chamber to another, liquid from chamber 4 overflows and passes through a sump, which is located at the outlet of chamber 4 , to the first constructed wetland with subsurface flow (SSF), which is the next element of the pilot plant. The first constructed wetland has a volume with a $22.95 \mathrm{~m}^{3}$ capacity, is filled with gravel and rocks with a wide range of sizes, has two vertical ventilation tubes and a residence time of 5 days. In the wetland, organic matter is degraded thanks to the interaction of the diverse plants which grow in it. The outflow of the constructed wetland is into a pond, arranged in series with the first constructed wetland. The pond has a $2 / 1$ length/width ratio, a volume with $90 \mathrm{~m}^{3}$ effective capacity, a depth of $1.5 \mathrm{~m}$ and a residence time of 8 days. Next to the pond, a second wetland is arranged in series, which has an identical design to the first wetland. In other, the pond is flanked on both sides by a constructed wetland, in such a way that the liquid of the pond is also in contact with the lateral wetlands. Finally, the stabilized effluent percolates to a final tank, which is arranged in series with the second wetland. The final tank has a $10.50 \mathrm{~m}^{3}$ capacity. The pilot plant has a recirculation circuit, which allows it to re-supply itself with the stabilized liquid of the pond. Global HRT is 27 days.

Construction of the pilot plants was started between June and November 2007, the chamber filling tests were performed in March 2008 and the plants began operation in May of the same year. For loading of digesters and ponds, the steps described below were followed:
1. Each digestion chamber and pond was initially filled with clean water, allowing verification of any leaks as well as the gradual adaptation of bacterial flora.

2. During the plant start-up period, slurry filling time depended on flow waste farm production.

3. External resources such as bacteria cultures, sewage sludge, etc., were not added. Therefore, waste degradation is produced through the activity of native bacterial flora.

\subsection{Parameters and samples}

A total of 46 samples were taken from plants $\mathbf{1}$ and 3, and 39 from Plant 2 (the lower number due to a sanitary stoppage from October 30th to December 30th, 2008). Samplings and measurements began on May 22nd, 2008, and ended on November 18th, 2009, making a total of 545 days. The measured parameters were: $p H$, temperature (T), electrical conductivity $(E C)$ and chemical oxigen demand $(C O D)$. The sampling design was carried out using the following criteria:

a) In the first six months, samples were taken once every week.

b) In the following six-month period, samples were taken once every fifteen days.

c) After the first twelve months, the analyses were carried out once every month.

The parameters were measured following standard methods (APHA 2005).

A meteorological station was installed on each farm, allowing the collection of ambient temperature $T_{A}$, relative humidity $\phi$, and rainfall levels $R_{a c c}$.

A subset of the sampled data was selected to analyze the operation behavior of the pilot plants over a complete cycle, in which the slurry passes through the plant. The selected subset is the one that corresponds with the samples taken every of the time period equal to the global $H R T$ for each pilot plant, being 81, 27 and 27 days for plants 1, 2 and 3 respectively. Therefore, it is necessary to identify sampling dates that differ among them approximately 82, 27 and 27 days. 131 samples are available, for the three plants, of which 30,21 and 21 sampling data are selected for each of plants respectively. At Appendix B, the information related to the samples is showed, with their respective global $H R T$ and dates.

\subsection{Statistical analysis}

The experimental parameters that are proposed to analyze statistically are $p H$, temperature $(T)$, electrical conductivity $(E C)$ and chemical oxigen demand $(C O D)$. For statistical analysis of the experimental data, for every one of the sampling point, is proposed to use these statistical parameters: sample mean $\bar{x}$, sample standard deviation $s_{N-1}$ represented by the expression (1), minimum $x_{\min }$ and maximum $x_{\max }$ values. The mean and the standard deviation can provide a simple and useful tool for the analysis of plant data, because they can provide direct information on the differences in the operation of the plant elements, and of the plants in general. In addition, the minimum and maximum values can also provide information about the stable operation of the plants, as well as outliers.

$s_{N-1}=\sqrt{\frac{1}{N-1} \sum_{i=1}^{N}\left(x_{i}-\bar{x}\right)^{2}}$

Besides, box plots are proposed to use in order to analyze the degree of dispersion and skewness in the sampled data, as well as to show 
outliers. The degree of dispersion of the sampled parameters turns out to be an important parameter, for the pilot plants, because is directly related to the stability of operation of the plants. In addition, in the case of the effluent from the farm, it can be intimately related with the fluctuating characteristic of the effluent parameters. Differences in the skewness of the sampled parameters, among the sampling points, could depict different operation features, probably provoked for various factors, such as temperature $T, p H$, etc.

\subsection{COD removal Efficiency (\%) and COD removal change rate (\%/day)}

The operation of the pilot plants and their elements can be evaluated by means of the variation of the $C O D$ throughout the plant, in the different sampling points from the input to the output. The variation of the $C O D$ throughout the plant or into each element can be affected by a diversity of factors, relative on the one hand, both to the design of the different elements and their disposition in the plant, and on the other hand to the values of the operation (effective flow rate $Q_{\text {eff }}$, farm effluent $C O D$, etc.) and atmospheric parameters. Therefore, it is interesting to obtain the removal efficiency of the $C O D$ referred to the sampling points, which allows to compare the operation of the plants and their elements. The expression (2) is proposed for determining the $C O D$ removal efficiency in every one of the sampling point $i$ with regard its $C O D$ mean value and of the previous one

$C O D_{R E(i)}=\frac{\overline{C O D}_{i-1}-\overline{C O D}_{i}}{\overline{C O D}_{1}} \cdot 100$

being $\overline{C O D}_{i}, \overline{C O D}_{i-1}$ and $\overline{C O D}_{1}$ the mean values of the chemical oxigen demands of the sampling point $i$, the previous one $i-1$ and the first sampling point of the pilot plant (Farm Effluent). It is also possible to define a $C O D$ removal efficiency with respect to any two sampling points $i$ and $j$, for its determination the expression (3) is proposed

$C O D_{R E(i-j)}=\frac{\overline{C O D}_{i}-\overline{C O D}_{j}}{\overline{C O D}_{1}} \cdot 100$

A specific application of expression (3) is to obtain the global COD removal efficiency that is estimated with respect the first and last sampling point (4).

For a same $C O D$ removal efficiency value of two different plants, the plant that offers better performance is one that needs less time to achieve the same removal of organic matter, in other words, the plant with less hydraulic retention time is better. From the above, it is possible to introduce a removal change rate for the plants by means of the ratio between the COD removal efficiency and the global hydraulic retention time expressed by (4).

$r_{G}=\frac{C O D_{R E(G)}}{H R T_{G}}$

With this ratio, it is possible to easily compare the performance of different plants with different size and operation. It is also possible to define this ratio to be applied between any two sampling points of the plant, represented by the expression (5)

$r_{i-j}=\frac{C O D_{R E(i-j)}}{H R T_{i j}}$

being $i$ and $j$ the two sample points, and $H R T_{i j}$ the hydraulic retention time between the sample points.

\section{Results and discussions}

\subsection{Atmospheric conditions}

The three pilot plants were influenced by atmospheric conditions, it is possible to observe this influence in subfigures $6(a)-6(b)-6(c)$ of
Table 2

Average values $\left(\bar{R}_{a c c}, \bar{\phi}\right)$.

\begin{tabular}{lcc}
\hline Plant & $\begin{array}{c}\overline{\mathbf{R}}_{\text {acc }} \\
\left(l / m^{2}\right)\end{array}$ & $\begin{array}{c}\bar{\phi} \\
(\%)\end{array}$ \\
\hline 1 & 68.11 & 77.56 \\
2 & 52.95 & 67.30 \\
3 & 41.46 & 63.50 \\
\hline
\end{tabular}

Table 3

Statistical data of the pilot plants.

\begin{tabular}{|c|c|c|c|c|c|c|}
\hline $\begin{array}{c}\text { Plant } \\
\left(N_{\text {samples }}\right)\end{array}$ & Parameter & Sampling point & $\begin{array}{c}\text { Mean } \\
(\bar{x})\end{array}$ & $\underset{\left(s_{N-1}\right)}{\text { SD }}$ & $\begin{array}{c}\text { Min } \\
\left(x_{\min }\right)\end{array}$ & $\begin{array}{c}\operatorname{Max} \\
\left(x_{\max }\right)\end{array}$ \\
\hline \multirow{10}{*}{$\begin{array}{c}1 \\
(30)\end{array}$} & \multirow{3}{*}{$\begin{array}{c}\text { COD } \\
(p p m)\end{array}$} & $F E$ & 29,773 & 5376 & 18,500 & 38,000 \\
\hline & & $P E$ & 24,273 & 4924 & 15,000 & 33,000 \\
\hline & & $T E$ & 8030 & 3025 & 3200 & 16,000 \\
\hline & \multirow{2}{*}{$\begin{array}{c}\mathbf{T} \\
(\circ C)\end{array}$} & $P S$ & 25.4 & 7.2 & 17.6 & 37.7 \\
\hline & & $A$ & 20.8 & 6.9 & 13.2 & 31.8 \\
\hline & \multirow[t]{2}{*}{$\mathrm{pH}$} & $F E$ & 7.6 & 0.2 & 7.0 & 8.0 \\
\hline & & $P S$ & 7.5 & 0.2 & 7.1 & 8.0 \\
\hline & \multirow{3}{*}{$\begin{array}{c}\mathbf{E C} \\
(m S / m)\end{array}$} & $F E$ & 16.4 & 1.2 & 14.0 & 18.7 \\
\hline & & $P S$ & 14.7 & 0.8 & 12.9 & 15.7 \\
\hline & & $T E$ & 11.9 & 2.4 & 6.2 & 15.5 \\
\hline \multirow{12}{*}{$\begin{array}{c}2 \\
(21)\end{array}$} & \multirow{3}{*}{$\begin{array}{l}\text { COD } \\
(p p m)\end{array}$} & $F E$ & 18,381 & 5551 & 10,500 & 27,600 \\
\hline & & $C h_{1}$ & 15,571 & 4488 & 8900 & 23,100 \\
\hline & & $\mathrm{Ch}_{6}$ & 3543 & 1583 & 1600 & 6500 \\
\hline & \multirow{3}{*}{$\begin{array}{c}\mathbf{T} \\
(\circ C)\end{array}$} & $C h_{1}$ & 20.9 & 7.1 & 12.1 & 34.0 \\
\hline & & $\mathrm{Ch}_{6}$ & 26.9 & 7.0 & 19.2 & 36.3 \\
\hline & & $A$ & 19.8 & 7.0 & 11.3 & 32.5 \\
\hline & \multirow[t]{3}{*}{$\mathrm{pH}$} & $F E$ & 6.1 & 0.7 & 5.1 & 7.7 \\
\hline & & $C h_{1}$ & 7.8 & 0.2 & 7.4 & 8.1 \\
\hline & & $\mathrm{Ch}_{6}$ & 8.5 & 0.3 & 8.1 & 9.0 \\
\hline & \multirow{3}{*}{$\begin{array}{c}\mathbf{E C} \\
(m S / m)\end{array}$} & $F E$ & 13.8 & 2.4 & 10.8 & 18.3 \\
\hline & & $C h_{1}$ & 12.6 & 1.7 & 10.1 & 15.8 \\
\hline & & $\mathrm{Ch}_{6}$ & 10.9 & 0.9 & 9.4 & 13.1 \\
\hline \multirow{18}{*}{$\begin{array}{c}3 \\
(21)\end{array}$} & \multirow{5}{*}{$\begin{array}{l}\text { COD } \\
(p p m)\end{array}$} & $C h_{1}$ & 21,424 & 3214 & 16,500 & 28,200 \\
\hline & & $\mathrm{Ch}_{2}$ & 10,333 & 3224 & 5100 & 17,000 \\
\hline & & $\mathrm{Ch}_{4}$ & 6336 & 1820 & 3900 & 10,500 \\
\hline & & $P B$ & 3752 & 1216 & 2500 & 7200 \\
\hline & & $T E$ & 1981 & 736 & 1000 & 3300 \\
\hline & \multirow{4}{*}{$\begin{array}{c}\mathbf{T} \\
(\circ C)\end{array}$} & $C h_{1}$ & 20.4 & 3.9 & 14.9 & 26.9 \\
\hline & & $\mathrm{Ch}_{2}$ & 22.5 & 3.8 & 17.5 & 28.6 \\
\hline & & $\mathrm{Ch}_{4}$ & 24.3 & 4.0 & 18.5 & 32.7 \\
\hline & & $A$ & 19.2 & 6.8 & 11.6 & 32.5 \\
\hline & \multirow[t]{4}{*}{$\mathrm{pH}$} & $C h_{1}$ & 6.3 & 1.0 & 5.1 & 9.4 \\
\hline & & $\mathrm{Ch}_{2}$ & 7.9 & 0.7 & 7.4 & 10.9 \\
\hline & & $\mathrm{Ch}_{4}$ & 7.9 & 0.5 & 5.8 & 8.3 \\
\hline & & $T E$ & 8.4 & 0.2 & 7.9 & 8.7 \\
\hline & \multirow{5}{*}{$\begin{array}{c}\mathbf{E C} \\
(m S / m)\end{array}$} & $C h_{1}$ & 16.1 & 1.4 & 13.6 & 18.6 \\
\hline & & $\mathrm{Ch}_{2}$ & 14.9 & 0.9 & 12.9 & 16.2 \\
\hline & & $\mathrm{Ch}_{4}$ & 14.6 & 1.1 & 12.5 & 16.7 \\
\hline & & $P B$ & 13.6 & 1.4 & 10.9 & 16.2 \\
\hline & & $T E$ & 10.1 & 2.5 & 6.4 & 14.0 \\
\hline
\end{tabular}

figure A.6, it was mainly due to the absence of temperature control in the digesters and/or in any other element (ponds, wetlands, ...), and besides the plants were exposed to rainfall, predominantly ponds and wetlands. On the other hand, the precipitations were invaluable from May to August, while for months from November to February precipitations were greater. Because the systems were open and subject to atmospheric conditions, such as rainfall contributions and evaporation losses (associated, among other causes, with the variability of relative humidity), the plant processes were influenced by modification of the liquid fraction, it has been quantified that the difference was around $5-20 \%$ in evaporation losses. It is shown in Table 2 the precipitation $\bar{R}_{a c c}$ and humidity $\bar{\phi}$ average values for the plants over the operation period. 


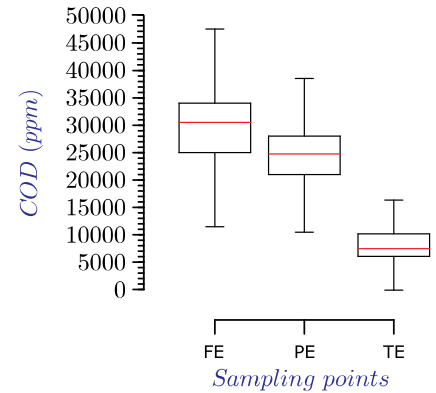

(a) Boxplot results for the $C O D$ of plant 1 .

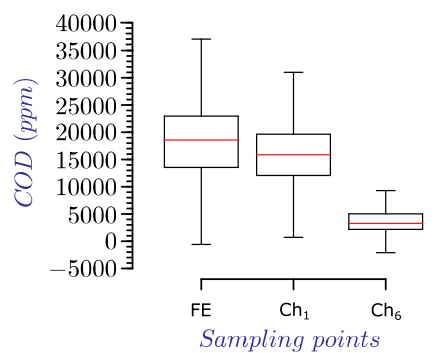

(b) Boxplot results for the $C O D$ of plant 2 .

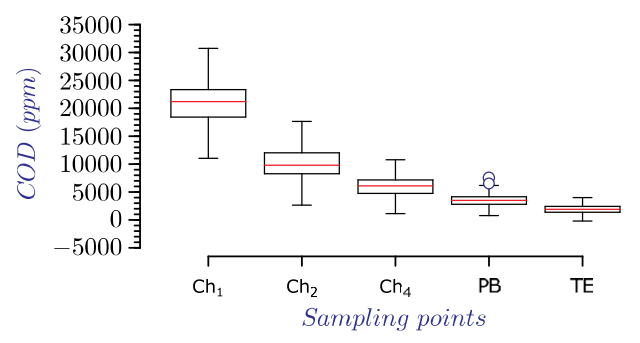

(c) Boxplot results for the $C O D$ of plant 3 .

Fig. 3. Boxplot results for the COD.

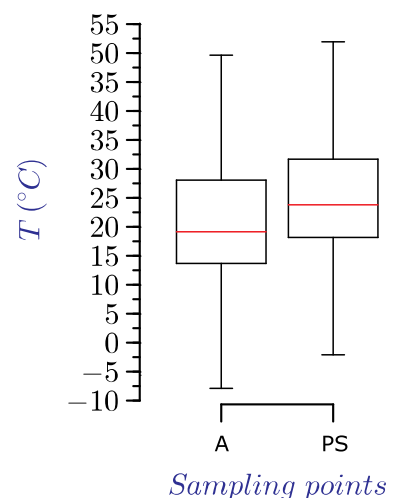

(a) Boxplot results for the temperature of plant 1 .

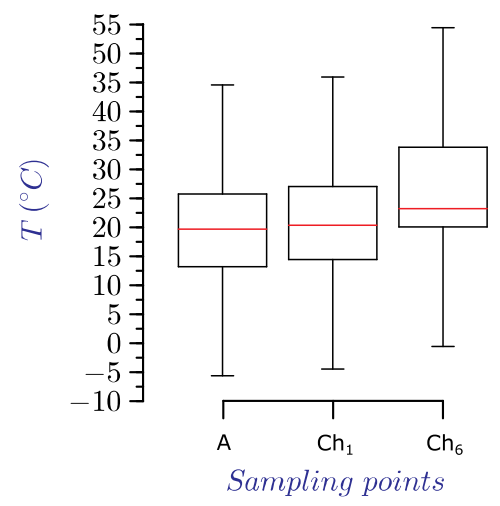

(b) Boxplot results for the temperature of plant 2.

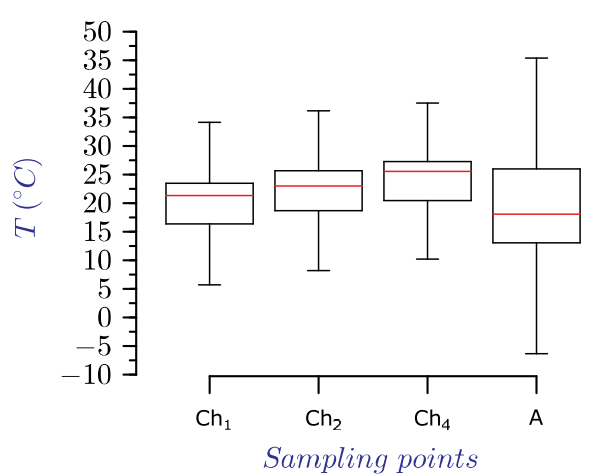

(c) Boxplot results for the temperature of plant 3

Fig. 4. Boxplot results for the temperature.

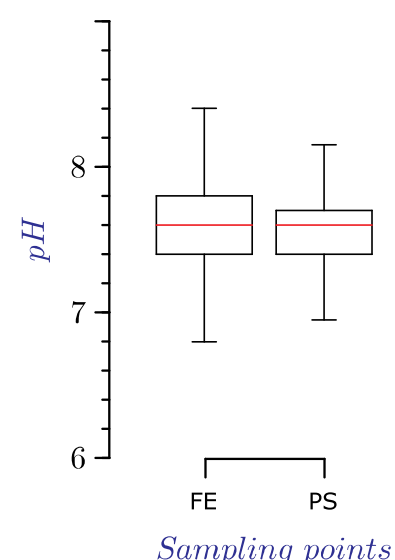

(a) Boxplot results for the $\mathrm{pH}$ of plant 1.

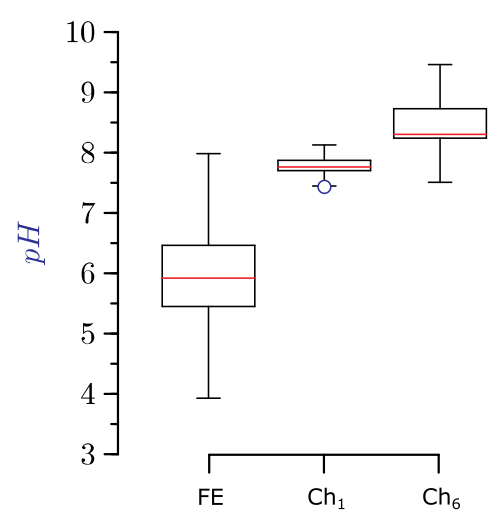

Sampling points

(b) Boxplot results for the $p H$ of plant 2 .

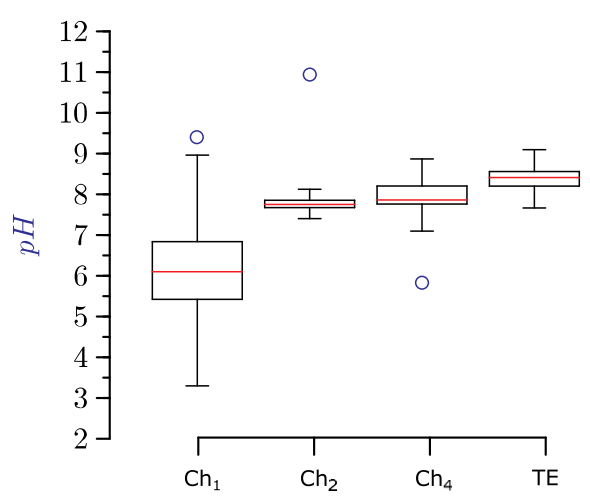

Sampling points

(c) Boxplot results for the $p H$ of plant 3 .

Fig. 5. Boxplot results for the $p H$.

\subsection{Statistical analysis of the results}

As proposed in subsection 2.4, the statistical results of the obtained data from the different sampling points are shown below in Table 3. Samples were selected with the indicated sampling frequency in tables of Appendix B (considering the global hydraulic retention times $H R T_{G}$ ). Besides, it is added at Appendix A the temporal evolutions of the analized parameters in Figs. 6-9.
For the analysis of the results of the plants, it is began with the input points. At the input, one of the operation parameters to be taken into account is the effective input flow rate $Q_{\text {eff }}$, which has different values: $13.6 \mathrm{~m}^{3} /$ day for the first plant, $6.4 \mathrm{~m}^{3} /$ day for the second, and $8.7 \mathrm{~m}^{3} /$ day for the third, as described above, these flows are stored in reception tanks, which for the three plants are different $13 \mathrm{~m}^{3}, 40 \mathrm{~m}^{3}$ and $10 \mathrm{~m}^{3}$ respectively. These reception tanks, in addition to complying with their mere storage function, also have a stabilizing effect on the slurry. From 
Table 4

COD removal efficiency values $\operatorname{COD}_{\mathbf{R E}(\mathbf{i}-\mathbf{j})}(\%)$ between different sampling points (i) - (j).

\begin{tabular}{|c|c|c|c|c|c|}
\hline Plant & $\begin{array}{l}\text { Screen } \\
(\%)\end{array}$ & $\begin{array}{l}\text { Digester } \\
(\%)\end{array}$ & $\begin{array}{c}\text { Screen }+ \text { Digester } \\
(\%)\end{array}$ & $\begin{array}{c}\text { Pond } \\
(\%)\end{array}$ & $\begin{array}{c}\text { Global } \\
(\%)\end{array}$ \\
\hline 1 & $\begin{array}{c}18.47 \\
(F E)-(P E)\end{array}$ & - & - & $\begin{array}{c}65.56 \\
(P E)-(T e)\end{array}$ & $\begin{array}{c}84.03 \\
(F E)-(T E)\end{array}$ \\
\hline 2 & $\begin{array}{c}15.28 \\
(F E)-\left(C h_{1}\right)\end{array}$ & $\begin{array}{c}65.43 \\
\left(C h_{1}\right)-\left(C h_{6}\right)\end{array}$ & $\begin{array}{c}80.71 \\
(F E)-\left(C h_{6}\right)\end{array}$ & - & $\begin{array}{c}80.71 \\
(F E)-\left(C h_{6}\right)\end{array}$ \\
\hline 3 & $\begin{array}{c}51.77 \\
\left(C h_{1}\right)-\left(C h_{2}\right)\end{array}$ & $\begin{array}{c}18.65 \\
\left(C h_{2}\right)-\left(C h_{4}\right)\end{array}$ & $\begin{array}{c}70.42 \\
\left(C h_{1}\right)-\left(C h_{4}\right)\end{array}$ & $\begin{array}{c}20.32 \\
\left(C h_{4}\right)-(T E)\end{array}$ & $\begin{array}{c}90.74 \\
\left(C h_{1}\right)-(T E)\end{array}$ \\
\hline
\end{tabular}

Table 5

COD removal change rate values $\mathbf{r}_{\mathbf{i}-\mathbf{j}}(\% /$ day) between different sampling points (i) $-(\mathbf{j})$.

\begin{tabular}{|c|c|c|c|c|}
\hline Plant & $\begin{array}{c}\text { Digester } \\
(\% / \text { day })\end{array}$ & $\begin{array}{c}\text { Screen + Digester } \\
(\% / \text { day })\end{array}$ & $\begin{array}{l}\text { Pond } \\
(\% / \text { day })\end{array}$ & $\begin{array}{c}\text { Global } \\
(\% / \text { day })\end{array}$ \\
\hline 1 & - & - & $\begin{array}{c}0.82 \\
(P E)-(T e)\end{array}$ & $\begin{array}{c}1 \\
(F E)-(T E)\end{array}$ \\
\hline 2 & $\begin{array}{c}3.11 \\
\left(C h_{1}\right)-\left(C h_{6}\right)\end{array}$ & $(F E)-\left(C h_{6}\right)$ & - & $\begin{array}{c}3 \\
(F E)-\left(C h_{6}\right)\end{array}$ \\
\hline 3 & $\begin{array}{c}2.33 \\
\left(C h_{2}\right)-\left(C h_{4}\right)\end{array}$ & $\begin{array}{c}5.8 \\
\left(C h_{1}\right)-\left(C h_{4}\right)\end{array}$ & $\begin{array}{c}1.34 \\
\left(C h_{4}\right)-(T E)\end{array}$ & $\begin{array}{c}3.3 \\
\left(C h_{1}\right)^{-(T E)}\end{array}$ \\
\hline
\end{tabular}

the information provided by the $C O D$, it can be inferred that the reception tank of plant 3 operates more stable than the other two, since its sample standard deviation $s_{N-1}=3212$ is considerably lower than in the other two cases $s_{N-1}=5376$ and $s_{N-1}=5551$. This fact can also be observed in the boxplots shown in Fig. 3, in which it can be seen that the height of the box, of the reception tank, is smaller than the others. One can also comment on the lack of data asymmetry shown by the three reception tanks, with respect to the $C O D$. With regard to the rest of the factors, it is possible to indicate that there is a temperature difference of $1^{\circ} \mathrm{C}$ with respect to the ambient temperature in the reception tanks of plants 2 and 3. This fact is probably associated with exothermic anaerobical processes. In the boxplots of Fig. 4, for the reception tank, a less dispersion is observed in plant 3 , and a slight asymmetry of the samples. The $p H$ in the reception tanks presents slightly acidic values and very similar in plants 2 and 3, and slightly basic in plant 1 . It can also be indicated that the $p H$ factor has less variability in plant 1 than in the other two, as reflected in the boxplots of Fig. 5 and Table 3. In general, with respect to the statistical results, it can be said that the operation in plant three is more stable, due to there is less data dispersion, especially in the $C O D$ parameter. It is also possible to mention that the $p H$ values at the outlet, for the three plants, are very similar.

\subsection{Results of removal efficiency $C O D_{R E(i j)}$ and removal change rate $r_{i-j}$}

By means of the application of equations (3) and (5), it is possible to establish the following considerations, which are also summarized in Tables 4 and 5. In general terms, for the three plants, the removal efficiency is higher than $80 \%$, and the best result is achieved on plant 3 with $90.75 \%$. This probably occurs because this plant integrates the strengths of the other two plants. Plant 3 has different areas of small size that favor the stabilization of the slurry and with it the bacterial activity, which after all is responsible for the degradation of the organic load. In addition, the batch process and the separation of the different zones encourage the growth rates of biomass in steady state. This last aspect can be observed in the values presented in the COD boxplots. On the other hand, the stability of the biological activity, in the digester of plant 3 , is favored because each loaded batch normally has a volume lower than the capacity of the digestion chambers, because after the slurry is sieved, from chamber 1 to chamber 2, the volume of the liquid fraction is less than the volume of the chamber, whose capacity is $24 \mathrm{~m}^{3}$. This aspect does not occur in the digester of plant 2 , where the digestion chambers have a capacity of $22 \mathrm{~m}^{3}$ and the reception tank has a capacity of $40 \mathrm{~m}^{3}$, so when the residue is sieved the content of more than one digestion chamber is displaced in the digester, causing a kind of reset of an important part of the digester from the point of view of the biological activity. Table 4 shows that the removal efficiency of the screen and digesters is $70.42 \%$, and for plant 2 it is $80.71 \%$, although at first sight the second case is greater, the digester of plant 3 has a capacity of $29 \mathrm{~m}^{3}$ lower than that of plant 2 , and also in the boxplots smaller dispersions are shown in all the sampling points, which could indicate a more stable biological activity.

On the other hand, the zone of the plant 3 associated to the lagoon and the wetlands has a better removal efficiency than the plant 1 , even though it is of a much smaller volume, probably due to the fact that the slurry is already fairly stabilized when it reaches this area, and also because the level of exposure to atmospheric conditions is lower.

Finally, regarding the $C O D$ removal change rate in Table 5, it can be seen that the plant 3 shows the best values in the two zones with respect to the other two plants, screen + digester and pond + wetland, and also with respect to the global ratio. These results are caused because the $H R T$ in the different elements are lower or equal in the plant 3 than in the other plants, showing similar or higher values of the removal efficiency.

\section{Conclusions}

The suitability of NTSW for treating effluent from pig farms, in Gran Canaria Island, has been tested. The three livestock farms currently have the possibility of either reusing the plant effluent, or discharging it to the sewage system under better conditions than previously. It has been showed that preliminary separation (using a rotary screen) is essential for a good system operation, avoiding obstruction problems. Ponds, when combined with constructed wetlands (inlet and outlet), have superior removal efficiencies with lower capacities and residence times, probably, that is the reason because the best design is given in plant 3 . It has the best performance, although it has more elements.

\section{Acknowledgments}

This research work has been carried out within the Livestock Industry Modernization Program of the Cabildo de Gran Canaria (Government of the island), and with the inestimable help of the farmers and the technical staff of the Agrarian Extension and Agricultural Development Service, Agrofood and Phytopathological Laboratory of the Cabildo de Gran Canaria and Analytical Control of Environmental Sources (CAFMA), Institute for Environmental Studies and Natural Resources (i-UNAT) of the University of Las Palmas de Gran Canaria. 
Appendix A. Temporal evolution of the analized parameters

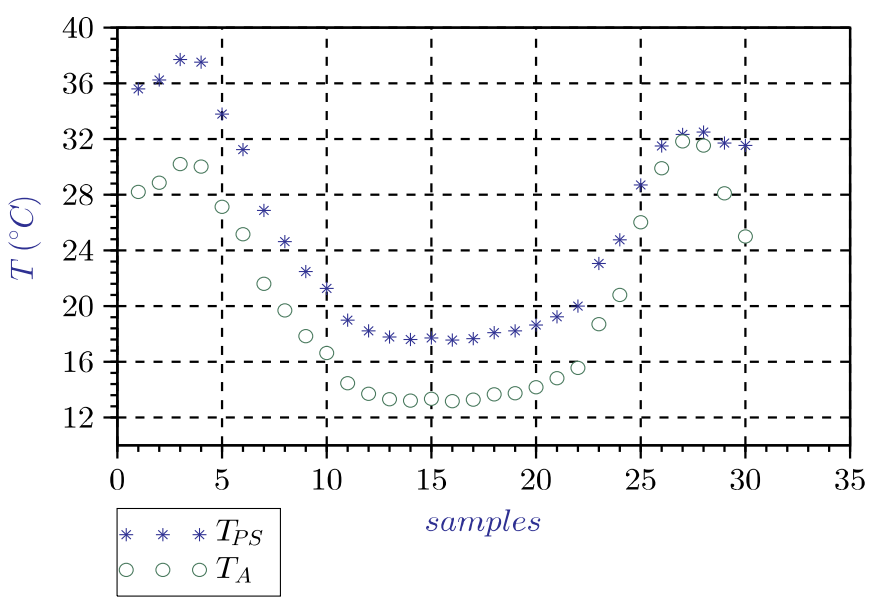

(a) Temperature results for plant 1 .

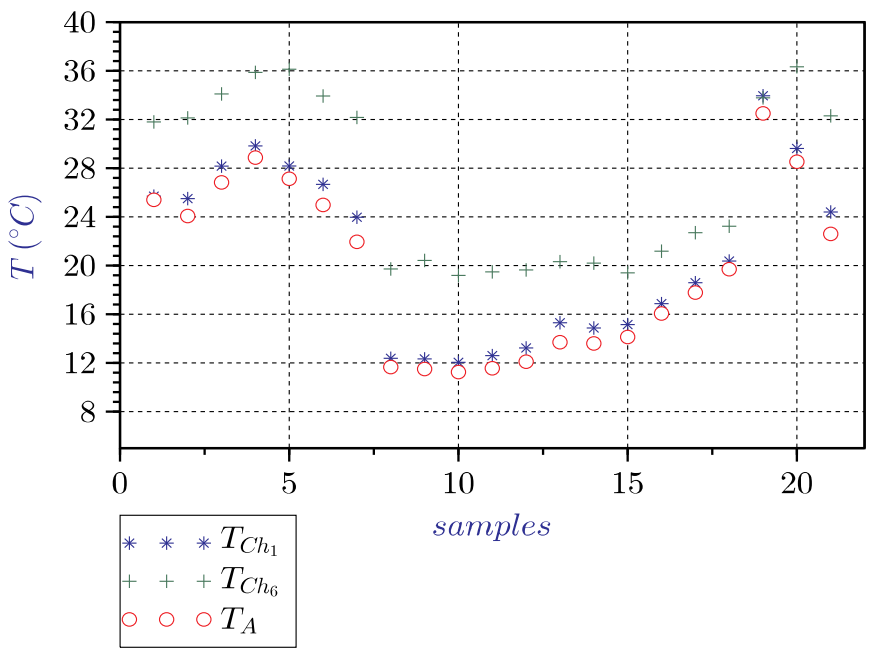

(b) Temperature results for plant 2 .

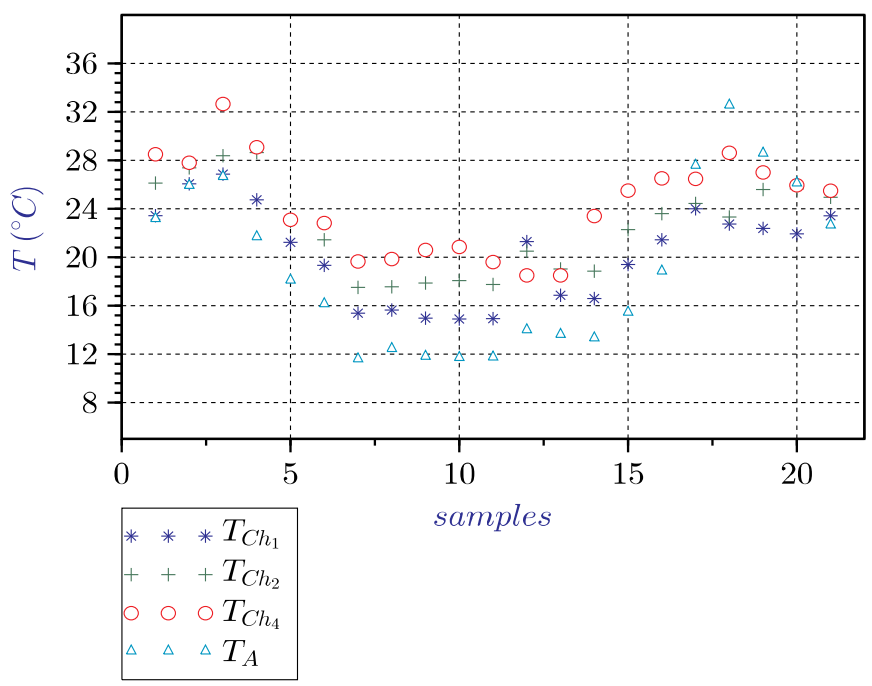

(c) Temperature results for plant 3 .

Fig. A.6. Temperature results for the plants.

The time evolution of the studied variables, in the different sampling points, can be analyzed in the graphs represented in the following figures: the behavior of the temperatures in Fig. 6(a)-(c), the values of $C O D$ in Fig. 7(a)-(c), the values of EC in Fig. 8(a)-(c), and finally the response of the values of $p H$ in Fig. 9(a)-(c). 


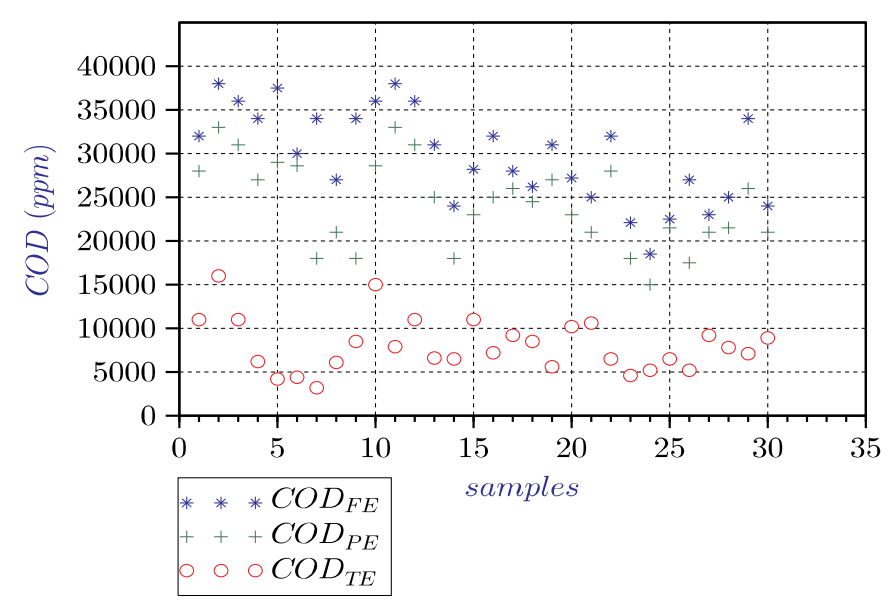

(a) COD results for plant 1 .

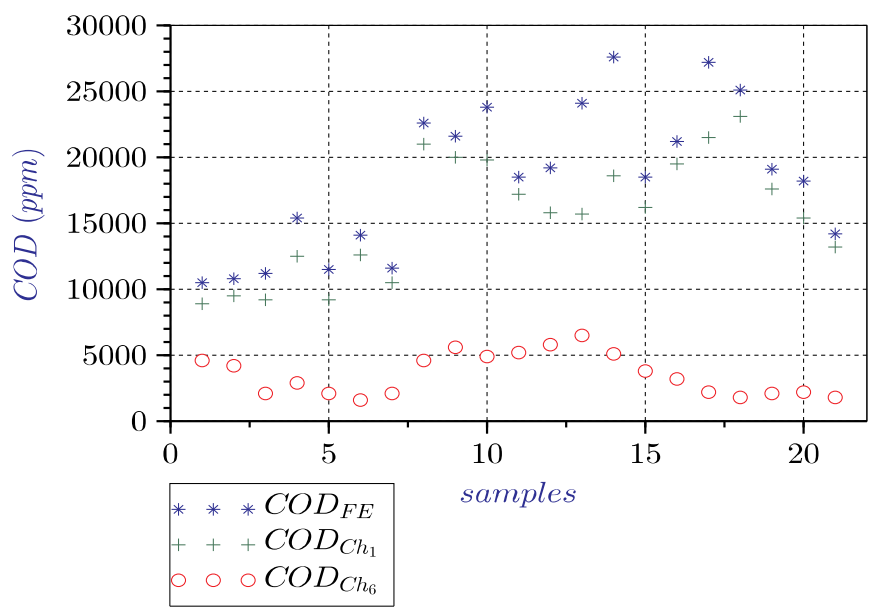

(b) $C O D$ results for plant 2 .

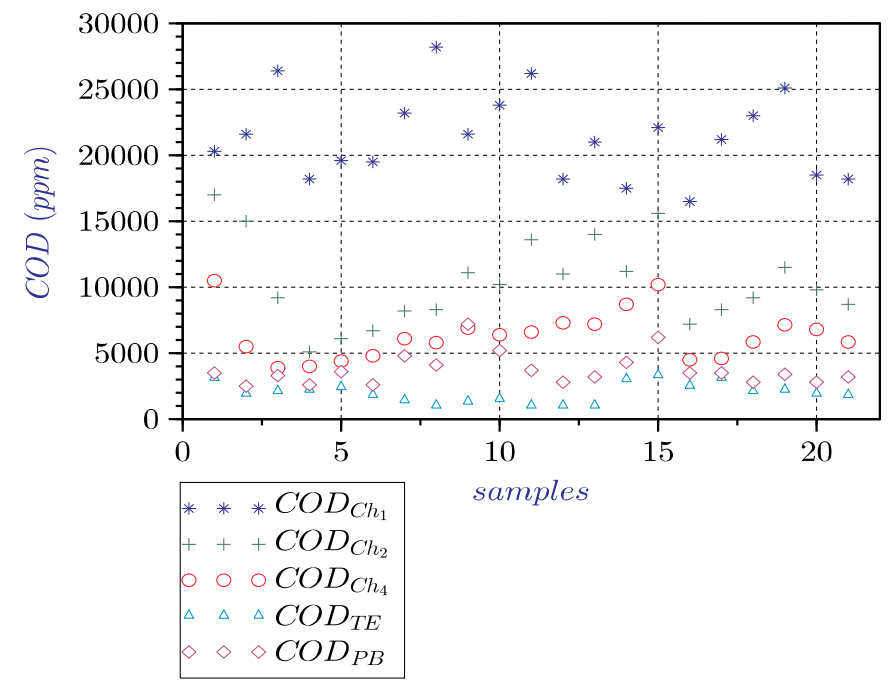

(c) COD results for plant 3 .

Fig. A.7. $C O D$ results for the plants. 


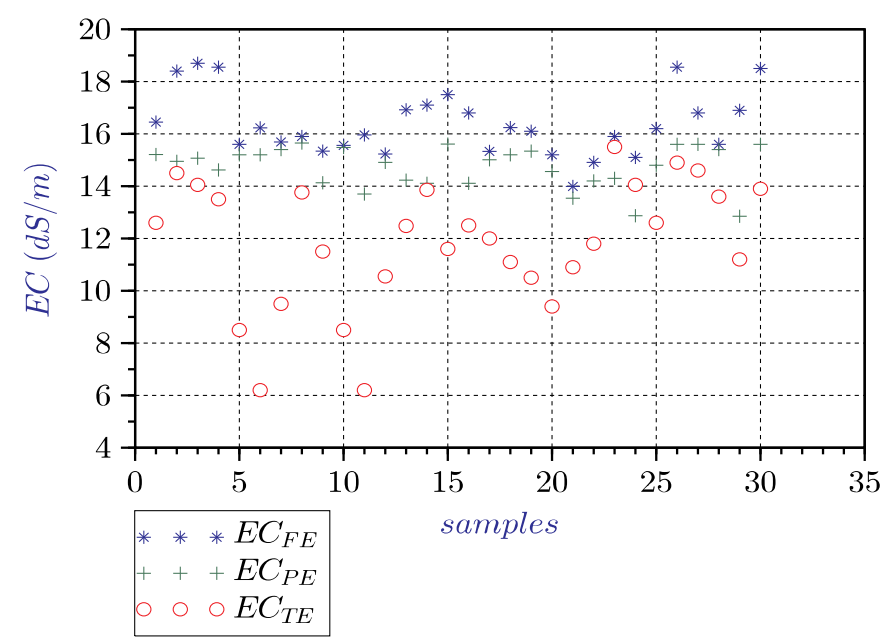

(a) Electrical conductivity results for plant 1 .

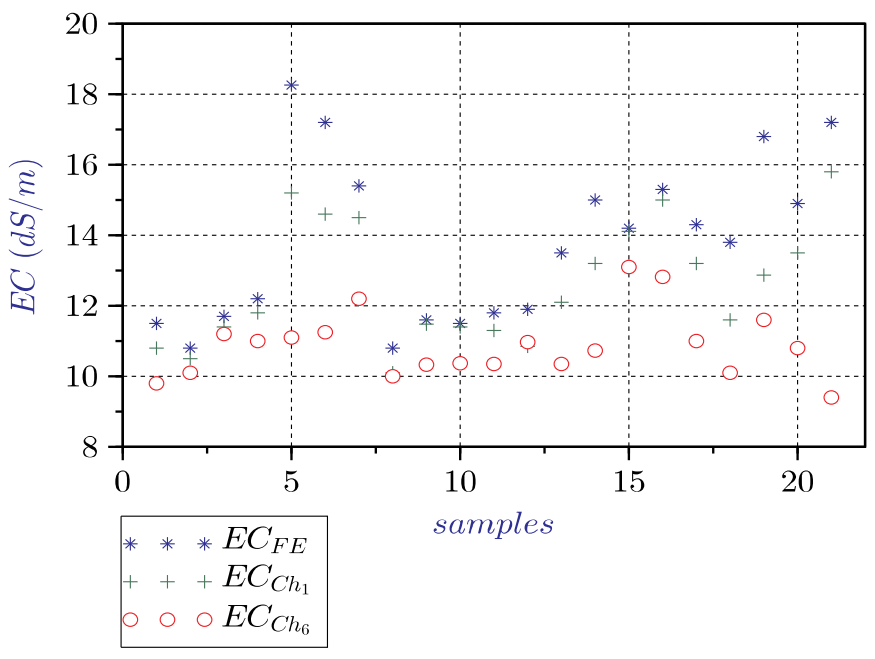

(b) Electrical conductivity results for plant 2 .

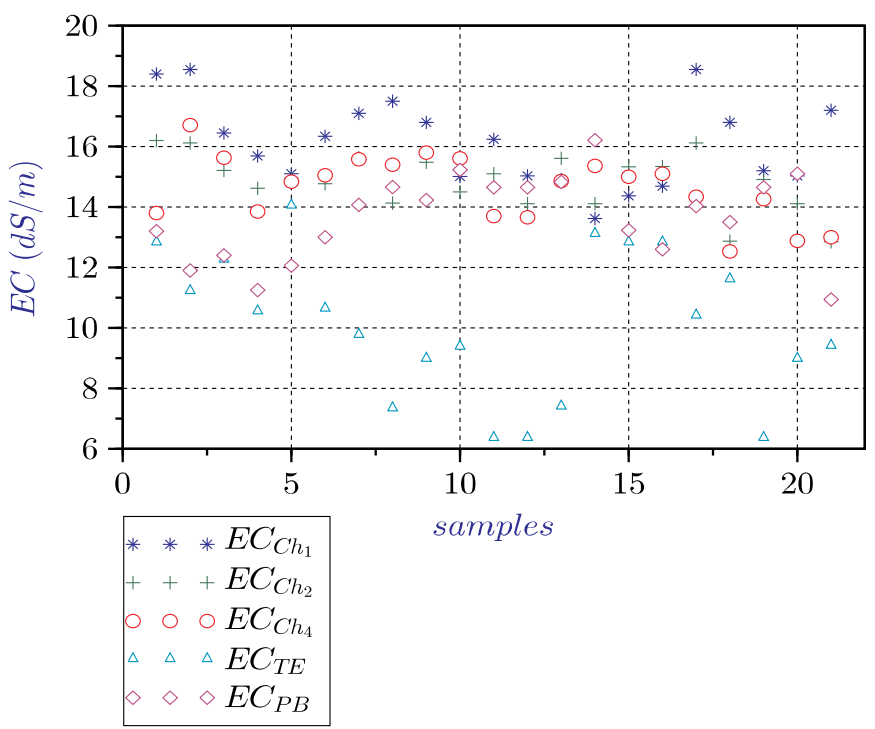

(c) Electrical conductivity results for plant 3 .

Fig. A.8. Electrical conductivity results for the plants. 


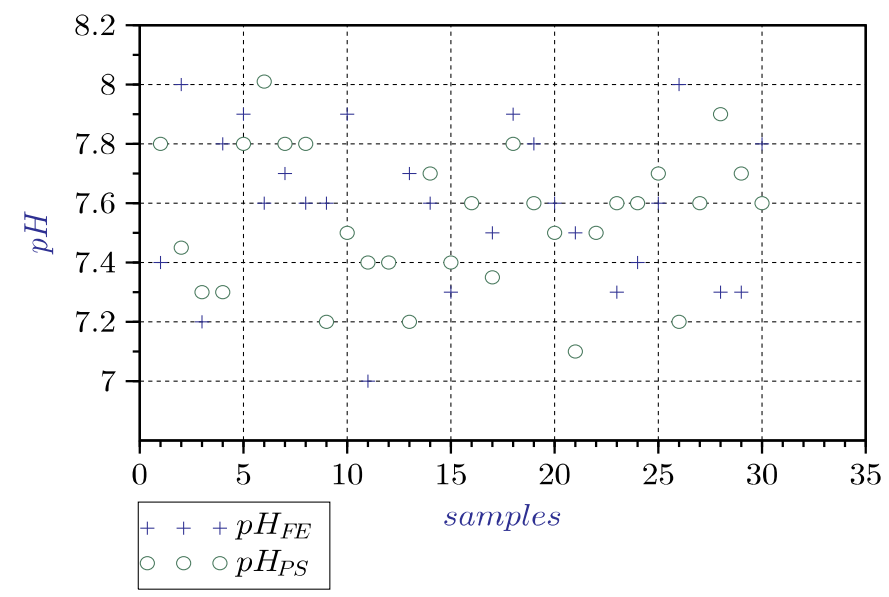

(a) $p H$ results for plant 1 .

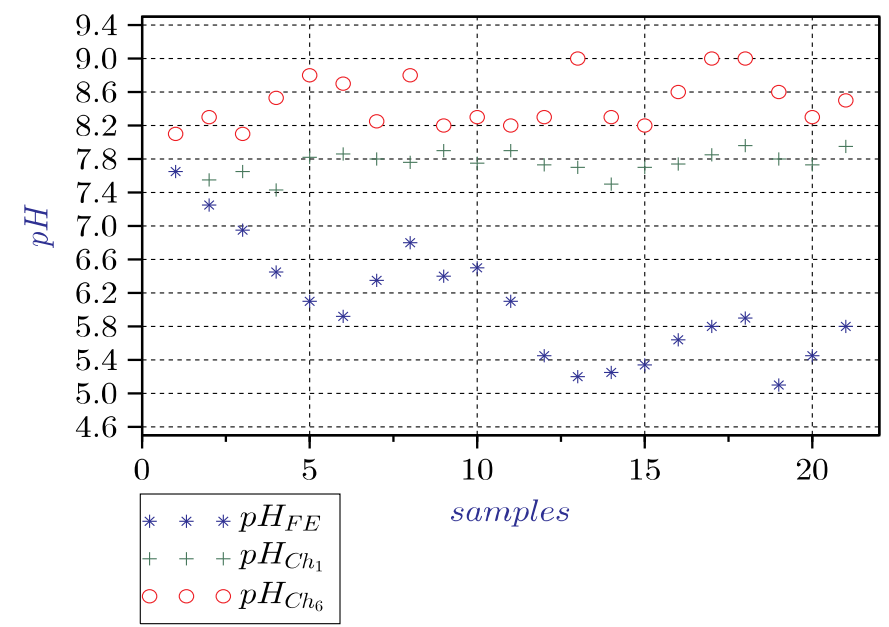

(b) $\mathrm{pH}$ results for plant 2 .

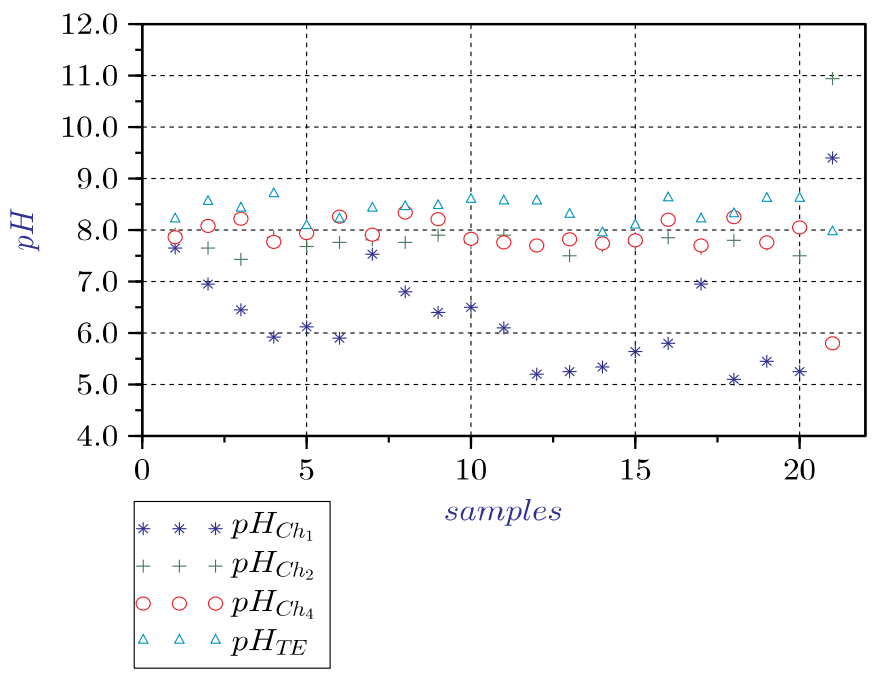

(c) $p H$ results for plant 3 .

Fig. A.9. $p H$ results for the plants.

\section{Appendix B. Temporal information of the samples}

In this appendix the information related to the sampling of the data, for the three plants, is presented. In the table $A .6$ for the plant $\mathbf{1}$, in the table A. 7 for the plant 2 , in the table $A .8$ for the plant 3 . 
Table B.6

Samples for plant 1 .

\begin{tabular}{|c|c|c|c|}
\hline $\begin{array}{c}\text { Monthly range } \\
(\text { Month DD - Month DD) }\end{array}$ & Year & $\begin{array}{r}\mathbf{H R T}_{\mathbf{G}} \\
(\text { day })\end{array}$ & Sample \\
\hline May 22 - July 31 & 2008 & 70 & 1 \\
\hline June 12 - August 14 & 2008 & 84 & 2 \\
\hline June 19 - September 04 & 2008 & 84 & 3 \\
\hline July 17 - September 18 & 2008 & 83 & 4 \\
\hline August 14 - October 23 & 2008 & 84 & 5 \\
\hline August 28 - November 06 & 2008 & 84 & 6 \\
\hline September 18 - November 27 & 2008 & 84 & 7 \\
\hline September 25 - December 11 & 2008 & 84 & 8 \\
\hline October 30 - January 15 & 2008 & 84 & 9 \\
\hline November 06 - January 22 & 2009 & 84 & 10 \\
\hline November 27 - February 05 & 2009 & 84 & 11 \\
\hline December 04 - February 19 & 2009 & 84 & 12 \\
\hline December 11 - February 26 & 2009 & 84 & 13 \\
\hline December 30 - March 05 & 2009 & 84 & 14 \\
\hline January 15 - March 19 & 2009 & 84 & 15 \\
\hline January 22 - April 02 & 2009 & 84 & 16 \\
\hline January 29 - April 16 & 2009 & 84 & 17 \\
\hline February 05 - April 22 & 2009 & 79 & 18 \\
\hline February 12 - April 30 & 2009 & 77 & 19 \\
\hline February 19 - May 07 & 2009 & 84 & 20 \\
\hline February 25 - May 14 & 2009 & 83 & 21 \\
\hline March 19 - May 27 & 2009 & 84 & 22 \\
\hline April 16 - June 18 & 2009 & 84 & 23 \\
\hline April 22 - July 02 & 2009 & 84 & 24 \\
\hline May $14-$ July 31 & 2009 & 83 & 25 \\
\hline June 01 - August 14 & 2009 & 79 & 26 \\
\hline July 02 - September 03 & 2009 & 77 & 27 \\
\hline July 31 - September 18 & 2009 & 78 & 28 \\
\hline August 14 - October 20 & 2009 & 81 & 29 \\
\hline September 18 - November 18 & 2009 & 76 & 30 \\
\hline
\end{tabular}

Table B.7

Samples for plant 2.

\begin{tabular}{|c|c|c|c|}
\hline $\begin{array}{c}\text { Monthly range } \\
\text { (Month DD - Month DD) }\end{array}$ & Year & $\begin{array}{l}\mathbf{H R T}_{\mathbf{G}} \\
(\text { day })\end{array}$ & Sample \\
\hline May 22 - June 19 & 2008 & 28 & 1 \\
\hline June 19 - July 17 & 2008 & 28 & 2 \\
\hline July 17 - August 14 & 2008 & 28 & 3 \\
\hline July $31-$ August 28 & 2008 & 28 & 4 \\
\hline August 25 - September 28 & 2008 & 28 & 5 \\
\hline September 18 - October 16 & 2008 & 28 & 6 \\
\hline September 25 - October 23 & 2008 & 28 & 7 \\
\hline January 15 - February 12 & 2009 & 28 & 8 \\
\hline January 22 - February 19 & 2009 & 28 & 9 \\
\hline January 29 - February 26 & 2009 & 28 & 10 \\
\hline February 05 - March 05 & 2009 & 28 & 11 \\
\hline February 19 - March 19 & 2009 & 28 & 12 \\
\hline March $05-$ April 02 & 2009 & 28 & 13 \\
\hline March 19 - April 16 & 2009 & 28 & 14 \\
\hline April $02-$ April 30 & 2009 & 28 & 15 \\
\hline April 16 - May 14 & 2009 & 28 & 16 \\
\hline April $30-$ May 27 & 2009 & 28 & 17 \\
\hline May 14 - June 11 & 2009 & 28 & 18 \\
\hline June 18 - July 02 & 2009 & 29 & 19 \\
\hline September 03 - October 01 & 2009 & 28 & 20 \\
\hline October 20 - November 18 & 2009 & 29 & 21 \\
\hline
\end{tabular}


Table B. 8

Samples for plant 3.

\begin{tabular}{|c|c|c|c|}
\hline $\begin{array}{c}\text { Monthly range } \\
\text { (Month DD - Month DD) }\end{array}$ & Year & $\begin{array}{r}\mathbf{H R T}_{\mathbf{G}} \\
(\text { day })\end{array}$ & Sample \\
\hline June 19 - July 18 & 2008 & 28 & 1 \\
\hline July 17 - August 14 & 2008 & 28 & 2 \\
\hline July 31 - August 28 & 2008 & 28 & 3 \\
\hline September 18 - October 16 & 2008 & 28 & 4 \\
\hline October 16 - November 13 & 2008 & 28 & 5 \\
\hline November 13 - December 11 & 2008 & 28 & 6 \\
\hline December 30 - January 28 & 2009 & 30 & 7 \\
\hline January 15 - February 12 & 2009 & 28 & 8 \\
\hline January 22 - February 19 & 2009 & 28 & 9 \\
\hline January 29 - February 26 & 2009 & 28 & 10 \\
\hline February 05 - March 05 & 2009 & 28 & 11 \\
\hline March $05-$ April 02 & 2009 & 28 & 12 \\
\hline March $19-$ April 16 & 2009 & 28 & 13 \\
\hline April $02-$ Abril 30 & 2009 & 28 & 14 \\
\hline April 16 - May 14 & 2009 & 28 & 15 \\
\hline April 30 - June 01 & 2009 & 32 & 16 \\
\hline June $01-$ July 02 & 2009 & 31 & 17 \\
\hline July $02-$ July 31 & 2009 & 29 & 18 \\
\hline September 03 - October 01 & 2009 & 28 & 19 \\
\hline September 18 - October 20 & 2009 & 32 & 20 \\
\hline October 20 - November 18 & 2009 & 29 & 21 \\
\hline
\end{tabular}

\section{References}

Alfaro, M., Salazar, F., 09, 2005. Ganaderia y Contaminacion Difusa, Implicancion para el Sur de Chile. Agric. Tec. (Santiago) 65, 330-340.

Alvarez-Romero, J.G., Wilkinson, S.N., Pressey, R.L., Ban, N.C., Kool, J., Brodie, J., 2014. Modeling catchment nutrients and sediment loads to inform regional management of water quality in coastal-marine ecosystems: a comparison of two approaches. J. Environ. Manag. 146, 164-178.

Ayaz, S., Aka, L., 2001. Treatment of wastewater by natural systems. Environ. Int. 26 (3), 189-195 international conference on ecotoxicology and environmental safety.

Ayaz, S., Akca, I., 2000. Treatment of wastewater by constructed wetland in small settlements. Water Sci. Technol. 41 (1), 69-72.

Basset-Mens, C., van der Werf, H.M., 2005. Scenario-based environmental assessment of farming systems: the case of pig production in France. Agric. Ecosyst. Environ. 105 (1), 127-144.

Belmont, M.A., Cantellano, E., Thompson, S., Williamson, M., Snchez, A., Metcalfe, C.D., 2004. Treatment of domestic wastewater in a pilot-scale natural treatment system in central Mexico. Ecol. Eng. 23 (4), 299-311.

Bennett, J.M., Warren, B., 2015. Role of livestock effluent suspended particulate in sealing effluent ponds. J. Environ. Manag. 154 (Suppl. C), 102-109.

Bernal, D., Cardona, D., Galvis, A., Pena, M., 2008. Guia de seleccion de tecnologia para el tratamiento de aguas residuales domesticas por metodos naturales. In: In: del Valle/ Instituto Cinara, U. (Ed.), Seminario Internacional sobre metodos naturales para el tratamiento de aguas residuales 1 of 1 . Universidad del Valle/Instituto Cinara, Instituto Cinara, Colombia, pp. 9.

Caballero-Lajarin, A., 2013. Sistema de depuracion de aguas residuales de origen ganadero. humedales artificiales. Ph.D. thesis, Universidad Politecnica de Cartagena, Cartagena, Spain.

Caballero-Lajarin, A., Faz, A., Lobera, J., 2008. Constructed wetland application to remove the pollution of waste water from pig farms. In: gradation. Vol. 1 of 1 . Italy. 5th International Conference on Land Depp. 9.

Campos, E., Flotats-Ripoll, X., 2001. Hacia la gestion integrada y co-tratamiento de residuos organicos. Retema: Revista tecnica de medio ambiente 81 (14), 838-846.

Crites, R., Middlebrooks, E.J., Bastian, R., 7, 2014. second ed. Natural Wastewater Treatment Systems 1 of 1 CRC Press Taylor and Francis Group.

Escribano-Pintor, S., Fernandez-Pulido, L., Aug, 2010. Riesgos medioambientales vinculados a la ganaderia en la sierra de san vicente. Obervatorio medioambiental 12 , $115-132$.

Gachango, F.G., Pedersen, S.M., Kjaergaard, C., Dec 2015. Cost-effectiveness analysis of surface flow constructed wetlands ( $\mathrm{sfcw}$ ) for nutrient reduction in drainage discharge from agricultural fields in Denmark. Environ. Manag. 56 (6), 1478-1486.

Gallego, A., 2014. Analisis territorial de la ganaderia de la comunidad valenciana mediante tecnologias sig y analisis multicriterio. Ph.D. thesis. Universidad Politecnica de Valencia, Valencia, Spain.

Gearheart, R.A., 1992. Use of constructed wetlands to treat domestic wastewater, city of arcata, California. Water Sci. Technol. 26 (7-8), 1625-1637.

Gobernment, C.I., 2001. Plan integral de residuos de canarias. Decreto 161/2001.
Gross, C., Hagy, J.D., 2017. Attributes of successful actions to restore lakes and estuaries degraded by nutrient pollution. J. Environ. Manag. 187, 122-136.

Hjorth, M., Christensen, K.V., Christensen, M.L., Sommer, S.G., Mar, 2010. Solid-liquid separation of animal slurry in theory and practice. a review. Agron. Sustain. Dev. 30 (1), 153-180.

Hopkins, K.G., Loperfido, J., Craig, L.S., Noe, G.B., Hogan, D.M., 2017. Comparison of sediment and nutrient export and runoff characteristics from watersheds with centralized versus distributed stormwater management. J. Environ. Manag. 203, 286-298.

Lopez, C., Mendieta, C., Lopez, A., Perez, S., 2008. Proceso para el tratamiento de residuos ganaderos en la isla de gran canaria. In: I Simposio Iberoamericano de Ingeniera de Residuos - REDISA 1 of 1 . Castellon, Spain, pp. 7.

Mabilde, L., Neve, S.D., Sleutel, S., 2017. Regional analysis of groundwater phosphate concentrations under acidic sandy soils: edaphic factors and water table strongly mediate the soil p-groundwater p relation. J. Environ. Manag. 203, 429-438.

Mannino, I., Franco, D., Piccioni, E., Favero, L., Mattiuzzo, E., Zanetto, G., Jan, 2008. A cost-effectiveness analysis of seminatural wetlands and activated sludge wastewatertreatment systems. Environ. Manag. 41 (1), 118-129.

Mendieta, C., Lopez, C., Perez, S., 2008. Evaluacion de sistemas de tratamiento no-convencional para efluentes procedentes de explotaciones ganaderas. In: I Simposio Iberoamericano de Ingeniera de Residuos - REDISA 1 of 1. Castellon, Spain, pp. 7.

Murgueitio, E., Aug 2003. Impacto ambiental de la ganaderia de leche en Colombia y alternativas de solucion. Livest. Res. Rural Dev, 15 (78), 118-129.

Perez-Rodriguez, P., Soto-Gomez, D., Paradelo, M., Lopez-Periago, J., 2017. Concentration levels of new-generation fungicides in throughfall released by foliar wash-off from vineyards. J. Environ. Manag. 203 (Part 1), 467-475.

Rivas, A., Singh, R., Horne, D., Roygard, J., Matthews, A., Hedley, M.J., 2017. Denitrification potential in the subsurface environment in the manawatu river catchment, New Zealand: indications from oxidation-reduction conditions, hydrogeological factors, and implications for nutrient management. J. Environ. Manag. 197, 476-489.

Vera, L., Martel, G., Marquez, M., 2013. Two years monitoring of the natural system for wastewater reclamation in santa lucia, gran canaria island. Ecol. Eng. 50, 21-30 research and innovation on ecotechnologies applied to improve wastewater treatment efficiency.

Vera, L., Martel, G., Salas, J.J., Sardon, N., Nogueira, R., Brito, A.G., Faby, J.-A., Ramon, A., 2009. Depuranat project: sustainable management of wastewater in rural areas. Desalination Water Treat. 4 (1-3), 59-68.

Vera-Pena, L., Martel-Rodriguez, G., Armas-Estevez, A., Toscon, A., Aug, 2005. Depuranat gestion sostenible del agua residual en los entornos rurales. Rincones del Atlantico $3,1-4$.

Xu, Z. Xin, Wei, Z., Yin, H. long, Huang, L. hui, 2010. Optimized design of natural ecological wastewater treatment system based on water environment model of dynamic mesh technique. J. Hydrodyn. Ser. B 22 (1), 1-8.

Yoon, C.G., Kim, S.-B., Kwun, T.-Y., Jung, K.-W., Jun, 2008. Development of natural and ecological wastewater treatment system for decentralized community in korea. Paddy Water Environ. 6 (2), 221-227. 